\title{
SH16 - Prueba comparativa para determinar el grado de incidencia que tienen los atributos: color, olor, sabor y textura
}

\author{
Marvin Estuardo Córdova Citalán \\ Sistema de Estudios de Posgrado \\ Universidad de San Carlos de Guatemala
}

\section{Resumen}

$\mathrm{E}$ 1 objetivo principal del estudio fue determinar el grado de incidencia que tienen los atributos: Color, Olor, Sabor y Textura en la intención de compra del consumidor de harina de maíz aplicado al canal de tortillería artesanal, en el municipio de El Progreso, Jutiapa, Guatemala. Se utilizaron cinco tipos de harina de maíz más comerciales de la región. La prueba comparativa se dividió en dos fases: a) Análisis de atributos en laboratorio, b) Fase de medición de percepción de los atributos para cada cliente en el canal de tortillería artesanal. Para el caso del atributo color se logró determinar que los valores de reflectancia entre $80 \%-83 \%$, son harinas con mejor grado de aceptación por el consumidor, las califica en la categoría "Me gusta mucho". Con respecto a los atributos olor y sabor, un hallazgo interesante es que existe relación entre los valores cuantificados de acidez en las harinas de maíz. Entre más baja es la acidez del de la harina de maíz indica que la materia prima es de una cosecha más reciente y que no ha pasado por largos periodos de almacenamiento. Los valores determinados en laboratorio fueron $22.26 \mathrm{mgKOH}$ (Maseca), $25.62 \mathrm{mgKOH}$ (El Comal), $27.45 \mathrm{mgKOH}$ (Chortimasa), $29.45 \mathrm{mgKOH}$ (Nixtamasa), $33.42 \mathrm{mgKOH}$ (Harimasa); las harinas de maíz con valores más bajos de acidez están

Palabras clave: Reflectancia, acidez mgKOH, perfil granulométrico, método Rotap, micrómetros, canal de tortillería artesanal.

\begin{abstract}
$\mathrm{T}$ The main objective of the study was to determine the degree of impact that have the attributes: color, odor, flavor and texture in purchase intent of consumers cornmeal applied to channel handmade tortilla, in the municipality of Progreso, Jutiapa, Guatemala. Five types of flour in the region most commercial corn were used. The comparative test was divided into two phases: a) Analysis laboratory attributes, b) Phase measuring perception of the attributes for each client in the channel handmade tortilla. In the case of color attribute it was determined that the reflectance values between $80 \%-83 \%$, are flours with better degree of consumer acceptance, qualifies in the category "I like a lot." With regard to odor and flavor attributes, an interesting finding is that there is a relationship between the quantized values of acidity in corn flour. Among lower the acidity of cornmeal indicates that the raw material is of a more recent vintage that has not gone through long periods of storage. The values determined in the laboratory were $22.26 \mathrm{mg} \mathrm{KOH}$ (Maseca), $25.62 \mathrm{mg} \mathrm{KOH} \mathrm{(El} \mathrm{Comal),} 27.45 \mathrm{mg} \mathrm{KOH}$ (Chortimasa), 29.45 mg KOH (Nixtamasa), $33.42 \mathrm{mg} \mathrm{KOH}$
\end{abstract}

